\title{
Pelatihan Guru Biologi dan Siswa SD-SMA/SMK di Pontianak untuk Meningkatkan Pengalaman Belajar di Bidang Bioteknologi
}

\author{
Exsyupransia Mursyanti, Stefani Santi Widhiastuti, Dewi Retnaningati \\ Universitas Atma Jaya Yogyakarta, Jalan Babarsari 43 Yogyakarta 55281 Indonesia $^{1}$ \\ Email: e.mursyanti@uajy.ac.id \\ Received 05 Juli 2021; Revised - ; Accepted for Publication 04 Januari 2022; Published 05 Januari 2022
}

\begin{abstract}
Pontianak is the center of education in the province of West Kalimantan. In the implementation of education and learning, the interaction between competent teachers and active students can improve the quality of education. Therefore, a service activity was made that aims to ensure quality educational services in accordance with the times. This service activity is entitled Training and Assistance for Biology Teachers and ElementarySMA/SMK Students at Karya Yosep Elementary School, St. Peter's Middle/High School, St. Mary's Vocational School with the theme Biotechnology and its Applications for the Welfare of Human Life. The method used is contextual learning which is packaged with a webinar model which includes 2 sessions, namely the delivery of material and discussion sessions. This activity is divided into 3 stages, namely the preparation, implementation, and evaluation stages. Overall, the activity went smoothly. This activity can increase the knowledge of Biology teachers and students in partner schools about the field of biotechnology, and participants can practice and apply the material received in everyday life. More than $85 \%$ of the participants from the group of teachers, elementary-junior high school students, and high school/vocational school students thought that the material provided was in accordance with the needs.
\end{abstract}

Keywords - training, teachers, students, biotechnology.

Abstrak- Pontianak merupakan pusat pendidikan di propinsi Kalimantan Barat. Pada pelaksanaan pendidikan dan proses pembelajaran, interaksi antara guru yang kompeten dan siswa yang aktif dapat meningkatkan kualitas pendidikan. Oleh karena itu, dibuat suatu kegiatan pengabdian yang bertujuan untuk menjamin proses pelayanan pendidikan memiliki mutu yang baik sesuai dengan perkembangan jaman. Kegiatan pengabdian ini berjudul Pelatihan dan Pendampingan Guru Biologi dan Siswa SDSMA/SMK di SD Karya Yosep, SMP/SMA St.Petrus, SMK St.Maria dengan tema Bioteknologi dan Aplikasinya bagi Kesejahteraan Hidup Manusia. Metode yang digunakan adalah contextual learning yang dikemas dengan model webinar dengan meliputi 2 sesi, yaitu sesi penyampaian materi dan diskusi. Kegiatan ini dibagi menjadi 3 tahap yaitu persiapan, pelaksanaan, dan evaluasi. Secara keseluruhan kegiatan berjalan dengan lancar. Kegiatan ini dapat meningkatkan pengetahuan guru-guru Biologi dan siswa-siswa di sekolah mitra tentang bidang bioteknologi, serta peserta dapat mempraktekkan dan mengaplikasikan materi yang diterima dalam kehidupan sehari-hari. Lebih dari $85 \%$ peserta dari kelompok guru, siswa SD-SMP, dan siswa SMA/SMK berpendapat materi yang diberikan sudah sesuai dengan kebutuhan.

Kata Kunci-pelatihan, guru, siswa, bioteknologi.

\section{PENDAHULUAN}

Kota Pontianak merupakan ibu kota propinsi Kalimantan Barat sekaligus pusat pendidikan di propinsi tersebut.
Berdasarkan data dari website kemendikbud.go.id, terdapat 199 Sekolah Dasar (SD) atau sederajat, 110 Sekolah Menengah Pertama (SMP) atau sederajat, dan 73 Sekolah Menengah Atas (SMA) atau sederajat di Pontianak. Sekolahsekolah tersebut tersebar di kecamatan Pontianak Barat, Pontianak Timur, Pontianak Kota, Pontianak Tenggara, dan Pontianak Selatan. Sebagai ibu kota propinsi, Pontianak diharapkan mampu memberikan fasilitas pembelajaran serta sistem pendidikan yang baik, mulai dari sarana dan prasarana hingga sumber daya manusianya, baik secara formal maupun informal ${ }^{[1]}$.

Guru memiliki peranan penting sebagai pendidik pada proses pendidikan dan pembelajaran. Interaksi antara guru yang kompeten dan siswa yang aktif dapat meningkatkan kualitas pendidikan. Pada kenyataannya, guru memiliki potensi yang beragam terutama dalam kemampuan menguasai materi serta ketrampilan menyampaikan materi tertentu sesuai bidang ilmunya.

Berdasarkan Peraturan Pemerintah (PP) 19 Tahun 2017 tentang guru dijelaskan bahwa perkembangan ilmu pengetahuan dan teknologi saat ini membawa dampak pada orientasi profesionalitas guru. Guru diarahkan untuk dapat mengmbangkan kompetensinya sesuai perkembangan zaman $^{[2]}$. Disebutkan dalam pasal 10 ayait (1) Undangundang Nomor 14 tahun 2005 tentang Guru dan Dosen, guru harus memiliki beberapa Kompetensi, salah satunya adalah kompetensi profesional ${ }^{[3]}$.

Guru Biologi diharapkan dapat meningkatkan kompetensinya dengan mengupgrade pengetahuan dan keterampilan mengenai Bioteknologi agar dapat menyampaikan pengalaman belajar tentang ilmu bioteknologi kepada siswa-siswanya secara menyeluruh. Guru dan siswa dapat mengupgrade ilmunya dengan berbagai cara baik melalui studi literature, diskusi dengan rekan, dan mengikuti seminar atau workshop terkait ilmu yang ditekuni.

Proses pengembangan kompetensi ini harus dilakukan terus menerus untuk menjamin pelayanan pendidikan yang diberikan guru memiliki mutu yang baik. Kompetensi ini salah satunya didukung oleh penguasaan materi belajar. Pada tanggal 30 Desember 2020, walikota Pontianak mengeluarkan surat edaran dengan Nomor: 421/897/satgas/Um/2020 tentang enyelenggaraan pendidikan semester genap tahun ajaran 2020/2021 dalam situasi Pandemi Covid-19 di Kota Pontianak. Surat edaran tersebut mengatur proses pelaksanaan pendidikan semua satuan pendidikan di Kota Pontianak, dimana proses pendidikan secara tatap muka ditiadakan hingga batas waktu yang belum ditentukan. Maka untuk mendukung program pemerintah, 
Pelatihan Guru Biologi dan Siswa SD-SMA/SMK di Pontianak untuk Meningkatkan

Pengalaman Belajar di Bidang Bioteknologi

kami mengadakan kegiatan pengabdian masyarakat yaitu Pelatihan dan Pendampingan Guru Biologi dan Siswa SDSMA/SMK di SD Karya Yosep, SMP/SMA St.Petrus, SMK St.Maria dengan tema Bioteknologi dan Aplikasinya bagi Kesejahteraan Hidup Manusia secara daring ${ }^{[4]}$.

Pengabdian ini telah mampu memberikan pengetahuan baru pada guru-guru Biologi dan siswa-siswa sekolah mulai dari tingkat SD hingga SMA/K dan meningkatkan motivasi peserta untuk melakukan penelitian atau membuat produk sederhana yang berkaitan dengan bidang bioteknologi di rumah.

\section{Metode Pengabdian}

Metode yang digunakan adalah "contextual learning", yaitu konsep belajar dengan menghubungkan materi yang diajarkan atau disampaikan dengan situasi di dunia nyata ${ }^{[5]}$ yang dapat meningkatkan kemampuan kognitif yaitu memahami materi yang dipelajari ${ }^{[6]}$. Dalam pelaksanaannya, metode ini diimplementasikan dengan model penyampaian materi secara langsung oleh narasumber dan dilanjutkan dengan diskusi.

Pelaksanaan kegiatan pengabdian ini dikemas dengan bentuk webinar yang interaktif. Materi yang disampaikan merupakan materi bidang bioteknologi yang memiliki kaitan erat dengan kehidupan sehari-hari. Dalam penyampaian materi, ditampilkan juga video yang menggambarkan proses suatu kegiatan sehingga peserta dapat lebih memahami isi materi, bahkan dapat mempraktekkan sendiri di rumah masing-masing.

Secara detail, tahapan kegiatan pengabdian dibagi menjadi 3 tahap:

\section{A. Tahap Persiapan: Koordinasi dengan pihak mitra}

Pada tahap ini, anggota pengabdi melakukan korespondensi dengan pengurus Yayasan Pendidikan Kalimantan sekaligus guru Biologi di salah satu sekolah mitra. Selanjutnya, kedua belah pihak berdiskusi terkait jadwal kegiatan, topik yang akan disampaikan dalam setiap pertemuan, peralatan yang diperlukan, hingga teknis pelaksanaan. Penyampaian materi disampaikan dalam 6x pertemuan dan dilanjutkan evaluasi kegiatan pada pertemuan ketujuh.

Kegiatan pengabdian dilaksanakan setiap hari Sabtu jam 11.00 WIB pada jadwal yang telah disepakati. Kegiatan dilansungkan dalam bentuk webinar, sehingga peralatan yang digunakan lebih sederhana, yaitu laptop atau PC, jaringan internet, dan platform google meet.

\section{B. Pelaksanaan: Penyampaian materi dengan presentasi, pemutaran video, dan diskusi}

Kegiatan webinar dilaksanakan mulai akhir bulan Maret 2021 hingga pertengahan bulan Mei 2021 sebanyak 6 kali dengan topik yang berbeda setiap pertemuannya. Selanjutnya pada pertemuan ketujuh ditutup dengan evaluasi evaluasi bersama perwakilan guru mitra. Setiap pertemuan berjalan kurang lebih selama 1 jam. Narasumber dan panitia memasuki platform google meet 30 menit sebelum kegiatan berlangsung. Peserta dipersilahkan bergabung 15 menit sebelum acara dimulai. Dalam pelaksanaan webinar, dipandu oleh 1 orang moderator dari perwakilan guru mitra. Webinar ini juga disiarkan melalui akun youtube mitra.

Narasumber menyampaikan materi kurang lebih selama 30 menit, dilanjutkan dengan pemutaran video dan diskusi.

Materi yang disampaikan dibagi dalam 3 kelompok peserta. Pertama, materi untuk guru-guru Biologi. Kedua, materi untuk siswa SD dan SMP. Ketiga, materi untuk siswa SMA dan SMK. Topik untuk keenam pertemuan adalah sebagai berikut:

Tabel 1. Topik Kegiatan Pengabdian

\begin{tabular}{|c|c|c|}
\hline Pertemuan & Topik & Peserta \\
\hline 1 & $\begin{array}{l}\text { Pengenalan \& penerapan } \\
\text { bioteknologi modern } \\
\text { dalam kehidupan sehari- } \\
\text { hari }\end{array}$ & $\begin{array}{l}\text { Guru-guru } \\
\text { Biologi }\end{array}$ \\
\hline 2 & $\begin{array}{l}\text { Grey bioteknologi sebagai } \\
\text { solusi penanganan } \\
\text { pencermaran lingkungan }\end{array}$ & $\begin{array}{l}\text { Guru-guru } \\
\text { Biologi }\end{array}$ \\
\hline 3 & $\begin{array}{l}\text { Sukseskan gerakan cuci } \\
\text { tangan: pembuatan jelly } \\
\text { soap }\end{array}$ & $\begin{array}{l}\text { Siswa SD } \\
\text { Karya Yosep } \\
\text { dan SMP } \\
\text { St.Petrus }\end{array}$ \\
\hline 4 & $\begin{array}{l}\text { Pelatihan aplikasi } \\
\text { bioteknologi melalui } \\
\text { kultur biji anggrek secara } \\
\text { in-vitro }\end{array}$ & $\begin{array}{l}\text { Guru-guru } \\
\text { Biologi }\end{array}$ \\
\hline 5 & $\begin{array}{l}\text { Aplikasi metode isolasi } \\
\text { dna tanaman sebagai } \\
\text { pendukung teknologi } \\
\text { rekayasa genetik }\end{array}$ & $\begin{array}{l}\text { Siswa } \\
\text { SMA/SMK } \\
\text { Karya Yosep } \\
\text { dan SMK } \\
\text { St.Maria }\end{array}$ \\
\hline 6 & $\begin{array}{l}\text { Pembuatan Edible Film } \\
\text { Dan Aplikasinya Dalam } \\
\text { Kemasan Pangan }\end{array}$ & $\begin{array}{l}\text { Siswa } \\
\text { SMA/SMK } \\
\text { Karya Yosep } \\
\text { dan SMK } \\
\text { St.Maria }\end{array}$ \\
\hline
\end{tabular}

\section{Evaluasi: evaluasi kegiatan oleh peserta}

Evaluasi dilakukan pada setiap pertemuan terhadap materi yang disampaikan, narasumber sebagai pemateri, metode penyampaian materi yang digunakan, maupun pelaksanaan kegiatan secara keseluruhan. Untuk mempersingkat waktu evaluasi, peserta diminta untuk mengisi google form yang berisi pertanyaan singkat terkait kegiatan pengabdian yang diikuti. 
Pelatihan Guru Biologi dan Siswa SD-SMA/SMK di Pontianak untuk Meningkatkan

Pengalaman Belajar di Bidang Bioteknologi

\section{HASIL DAN PEMBAHASAN}

Undang-undang Republik Indonesia Nomor 20 tahun 2003 tentang Sistem Pendidikan Nasional mendefinisikan pendidikan sebagai suatu usaha yang didasari oleh kesadaran dan perencanaan yang baik untuk dapat mewujudkan suasana belajar serta proses pembelajaran yang baik, sehingga peserta didik dapat mengembangkan potensi dirinya secara aktif dan memiliki tidak hanya kekuatan spiritual keagamanaan, namun juga pengendalian diri, kepribadian, kecerdasan, akhlak mulia, serta ketrampilan lain yang diperlukan oleh peserta didik itu sendiri, bangsa, dan negara ${ }^{[7]}$.

Penyelenggaraan pelatihan dan pendidikan merupakan bentuk upaya untuk meningkatkan pengetahuan dan kualitas dari sumber daya manusia ${ }^{[8]}$. Pandemi Covid-19 yang terjadi di seluruh duni saat ini juga memberikan dampak besar pada dunia pendidikan. Pemerintah mengeluarkan kebijakankebijakan untuk membatasi penyebaran virus Covid-19, salah satunya adalah dengan membatasi kegiatan sekolah secara luring. Semua kegiatan pembelajaran dialihkan menjadi bentuk daring, termasuk dengan kegiatan pelatihan bagi guru dan siswa.

Kegiatan pengabdian ini juga dilaksanakan secara daring tanpa tatap muka. Semua tahap mulai dari persiapan, pelaksanaan, hingga evaluasi juga dilakukan secara daring. Pelaksanaan program berjalan dengan lancar dan terlaksana tepat waktu, animo peserta pun tinggi. Hal ini bisa dilihat dari jumlah peserta yang hadir cukup banyak dan banyaknya pertanyaan yang diajukan pada sesi diskusi.

Topik yang dipilih dalam kegiatan pengabdian ini mewakili tiga bidang minat yang ada di Fakultas Teknobiologi, yaitu teknobio-industri, teknobio-pangan, dan teknobio-lingkungan. Sebenarnya bioteknologi di Indonesia telah berkembang sejak lama, terutama di bidang pangan. Namun bioteknologi modern mulai berkembang di Indonesia sejak tahun 1985, yaitu ketika diijinkannya pembukan program Bioteknologi di pendidikan tinggi oleh Menteri Pendidikan dan Kebudayaan saat itu ${ }^{[9]}$.

Perkembangan bioteknologi di bidang industri kesehatan dan tanaman dapat meningkatkan kualitas kesehatan masyarakat, serta menjaga kelestarian plasma nutfah. Perkembangan bioteknologi di bidang pangan dapat meningkatkan diversifikasi produk pangan dan menggali potensi bahan pangan lokal. Perkembangan bioteknologi di bidang lingkungan dapat meningkatkan restorasi lingungan yang tercemar, serta meningkatkan kualitas lingkungan bagi kehidupan manusia. Informasi-informasi ini yang ingin disampaikan kepada peserta pengabdian.

Dalam pelaksanaan webinar secara daring, terdapat beberapa kendala yang muncul, namun dapat segera teratasi. Kendala tersebut antara lain adalah narasumber kesulitan untuk share screen maupun share video melalui google meet karena tidak terbiasa menggunakan platform tersebut. Solusi yang dilakukan adalah melakukan gladi bersih sehari sebelum kegiatan seminar berlangsung serta menyerahkan materi ppt maupun video kepada operator sebagai backup jika terjadi kendala untuk share screen maupun video.
Gambar 1 menunjukkan contoh flyer dari kegiatan pengabdian yang diselenggarakan.

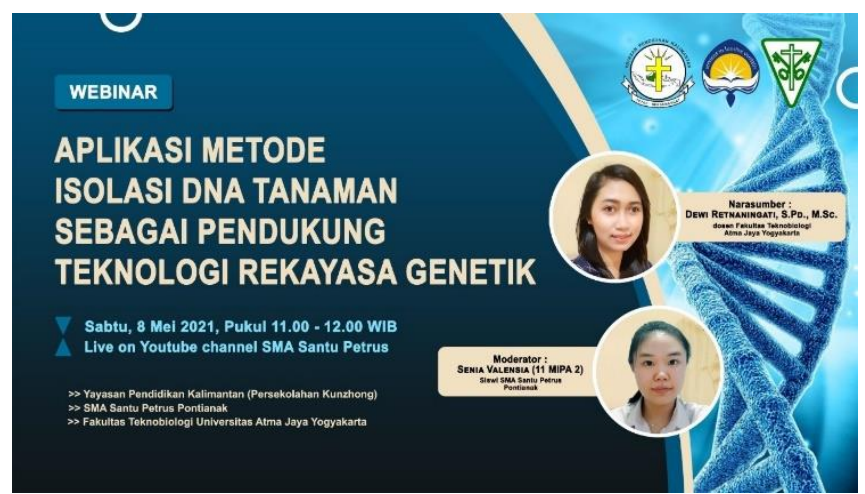

Gambar 1. Contoh flyer kegiatan pengabdian

Flyer kegiatan pengabdian disiapkan oleh pihak mitra dengan masukan dari anggota pengabdi. Flyer ini selanjutnya disebarkan secara online kepada calon peserta yang menjadi target kegiatan setidaknya satu minggu sebelum kegiatan berlangsung. Penggunaan flyer tersebut sangat efektif untuk menarik minat peserta.

Gambar 2 menunjukkan contoh tampilan youtube mitra pada saat kegiatan pengabdian berlansung.

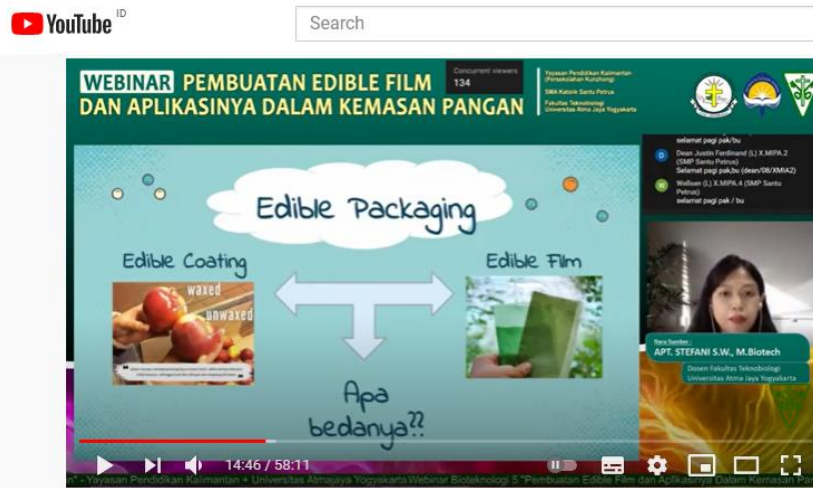

Pembuatan Edible Film dan Aplikasinya Dalam Kemasan Pangan

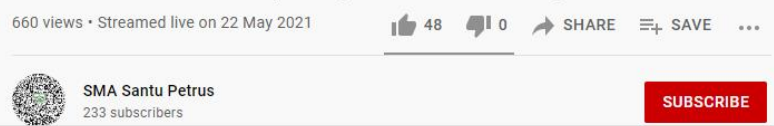

Gambar 2. Contoh tampilan youtube mitra pada saat kegiatan pengabdian berlansung.

Kegiatan webinar ini juga disiarkan melalui channel youtube mitra. Bagi peserta yang kesulitan untuk bergabung melalui google meet dapat kembali menonton jalannya webinar di channel youtube mitra. Peserta dari luar sekolah mitra juga dapat mengajukan pertanyaan di kolom chat youtube dan akan dibacakan oleh moderator saat sesi diskusi webinar berlangsung.

Gambar 3 menunjukkan dokumentasi kegiatan webinar bersama guru-guru Biologi melalui google meet. 


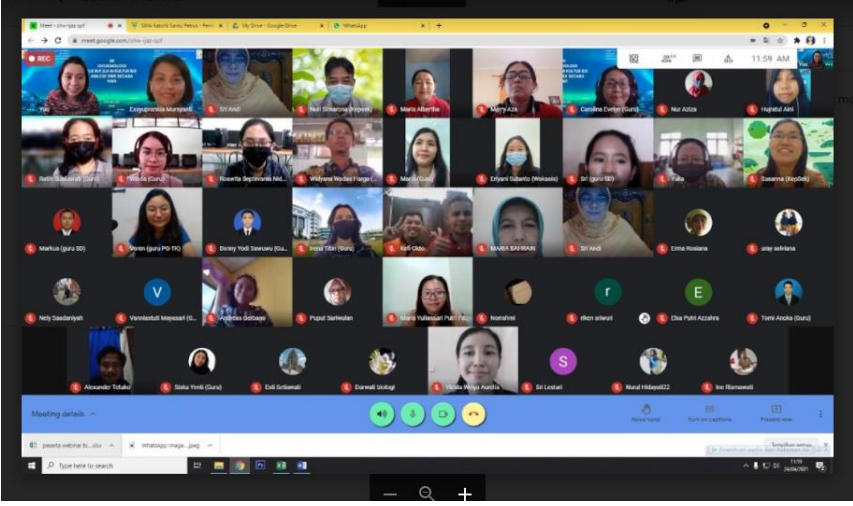

Gambar 3. Dokumentasi kegiatan webinar bersama guruguru Biologi melalui google meet

Selama kegiatan berlangsung, tidak semua peserta menyalakan kameranya karena keterbatasan jaringan. Meskipun demikian, peserta tetap aktif bertanya dan berdiskusi dengan narasumber, baik melalui kolom chat maupun bertanya secara langsung.

Evaluasi kegiatan meliputi penilaian terhadap kelengkapan materi yang disampaikan oleh narasumber, kemudahan metode yang digunakan narasumber dalam penyampaian materi untuk dipahami, kejelasan narasumber dalam menjawab pertanyaan, ketepatan waktu pelaksanaan kegiatan, dan kesesuaian materi yang disampaikan dengan kebutuhan.

Tabel 2 menunjukkan distribusi jumlah peserta kegiatan pengabdian.

\begin{tabular}{|c|c|c|}
\hline Kelompok & Peserta & Jumlah \\
\hline 1 & Guru-guru Biologi & 19 orang \\
\hline 2 & Siswa SD dan SMP & 236 orang \\
\hline 3 & Siswa SMA dan SMK & 95 orang \\
\hline
\end{tabular}

Pada tabel 2 tampak bahwa peserta terbanyak didominasi oleh siswa SD dan SMP, yaitu sebanyak 236 peserta. Jumlah guru paling sedikit dibandingkan jumlah siswa yang menjadi peserta karena hanya dibatasi pesertanya adalah guru mata pelajaran Biologi di sekolah mitra.

Gambar 4, 5, dan 6 berikut ini menunjukkan pendapat peserta dari ketiga kelompok terhadap kesesuaian topik yang diberikan dengan kebutuhan.

Materi yang disampaikan: 19 jawaban

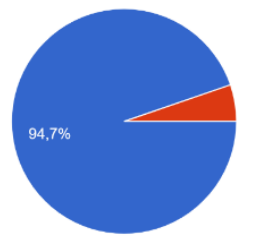

sesuai kebutuhan sangat tidak sesuai dengan kebutuhan

Gambar 1. Pendapat guru-guru Biologi terhadap kesesuaian materi kegiatan dengan kebutuhan
Materi yang disampaikan:

236 jawaban

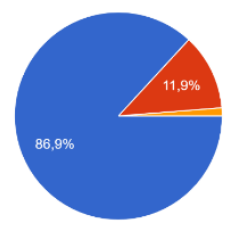

- sesuai kebutuhar

Gambar 2. Pendapat siswa SD dan SMP terhadap kesesuaian materi kegiatan dengan kebutuhan

Materi yang disampaikan:

95 jawaban

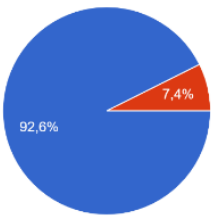

- sesuai kebutuhan

- sangat tidak sesua dengan rebutunar

Gambar 3. Pendapat siswa SMA dan SMK terhadap

kesesuaian materi kegiatan dengan kebutuhan

Dari ketiga kelompok tersebut, lebih dari $85 \%$ peserta menyatakan bahwa materi yang disampaikan dalam kegiatan pengabdian sudah sesuai dengan kebutuhan peserta. Pemilihan materi sendiri telah dipilih yang menarik, namun mudah diaplikasikan atau dipraktekkan sendiri oleh peserta di rumah masing-masing menggunakan peralatan dan bahanbahan yang sederhana.

Penilaian secara umum terhadap semua agenda kegiatan adalah materi disampaikan dengan lengkap, metode yang digunakan oleh narasumber mudah dipahami, narasumber dapat menjawab pertanyaan dengan jelas dan mudah dipahami, materi yang disampaikan sesuai dengan kebutuhan, serta pelaksaan kegiatan berjalan tepat waktu.

Indikator yang menjadi kendala pada proses pendidikan secara daring, yaitu permasalahan komunikasi, metode pembelajaran yang kurang menarik, materi ajar yang sulit, serta biaya dan penggunaan teknologi. Dalam kegiatan ini, keempat kendala tersebut tidak muncul. Hal ini dapat disebabkan karena latar belakang peserta yang berasal dari keluarga dengan tingkat ekonomi menengah hingga ekonomi atas sehingga telah terbiasa menggunakan teknologi yang sedang berkembang. Peserta juga tidak kesulitan berkomunikasi dan dapat dengan mudah mengakses informasi dari internet ${ }^{[10]}$.

Beberapa saran yang diberikan dan dapat menjadi bahan perbaikan di masa mendatang adalah dapat digunakan sarana/prasarana, aplikasi, maupun metode penyampaian materi yang lebih interaktif sehingga peserta lebih tertarik lagi untuk terlibat dalam diskusi dan dapat meningkatkan minat peserta untuk mempraktekkan langsung.

Usulan yang diberikan oleh peserta adalah dapat menyelenggarakan kegiatan serupa dengan peserta tidak dibatasi dari sekolah mitra saja, namun guru-guru Biologi maupun siswa sekolah secara umum, tidak hanya di 
Pelatihan Guru Biologi dan Siswa SD-SMA/SMK di Pontianak untuk Meningkatkan

Pengalaman Belajar di Bidang Bioteknologi

Pontianak. Narasumber dapat membawakan topik-topik yang berbeda dan dapat diaplikasikan dalam di rumah masingmasing.

\section{KESIMPULAN}

Setelah melakukan kegiatan pengabdian secara daring dengan peserta guru-guru Biologi dan siswa-siswa SD Karya Yosep, SMP/SMA St. Petrus dan SMK St. Maria Pontianak, dapat disimpulkan bahwa kegiatan pengabdian ini dapat meningkatkan kualitas pelaku pendidikan dengan meningkatkan pengetahuan guru-guru Biologi dan siswasiswa di sekolah mitra tentang bidang bioteknologi dan aplikasinya dalam kehidupan sehari-hari. Peserta pengabdian dapat mempraktekkan dan mengaplikasikan materi yang telah diberikan selama webinar dalam kehidupan sehari-hari.

\section{UCAPAN TERIMAKASIH}

Terima kasih diucapkan kepada Pimpinan Universitas, kepala Lembaga Penelitian dan Pengabdian pada masyarakat yang telah memberikan dana untuk pelaksanaan kegiatan pengabdian dan Dekan Fakultas Teknobiologi Universitas Atma Jaya Yogyakarta yang memberikan ijinnya untuk melakukan pengabdian ini. Tim Pengabdian juga mengucapkan terima kasih kepada Ibu Evelyn dan tim dari Yayasan Pendidikan Kalimantan, kepala sekolah, guru-guru biologi, serta siswa-siswa SD Karya Yosep, SMP/SMA St. Petrus dan SMK St. Maria yang telah bersedia bermitra dalam kegiatan ini.

\section{DAFTAR PUSTAKA}

[1] Jumlah Data Satuan Pendidikan (Sekolah) Per Kabupaten/Kota : Kota Pontianak.https://referensi.data.kemdikbud.go.id/index11.php?kode=13 6000\&level=2 . Diakses tanggal 15 Maret 2021

[2] Peraturan Pemerintah (PP) 19 Tahun 2017 tentang guru. Database Peraturan. https://peraturan.bpk.go.id/Home/Details/51474/pp-no-19tahun-2017

[3] Undang-Undang Nomor 14 tahun 2005 tentang Guru dan Dosen https://bphn.go.id/data/documents/08pp074.pdf

[4] Surat Edaran Walikota Pontianak Nomor: 421/897/satgas/Um/2020 tangal 30 Desember 2020 Perihal Penyelenggaraan pendidikan semester genap tahun ajaran 2020/2021 dalam situasi Pandemi Covid-19 di Kota Pontianak

[5] Rahayuningsih, Nuning, Ashadi, Sarwanto. 2013. Pembelajaran Biologi dengan Model CTL (Contextual Teaching and Learning) Menggunakan Media Animasi dan Media Lingkungan Ditinjau dari sikap Ilmiah dan Gaya Belajar. JURNAL INKUIRI ISSN: 2252-7893, Vol 2, No 2 (hal 173-183) http://jurnal.fkip.uns.ac.id/index.php/sains

[6] Andarini, Tri, Masykuri, Suciati Sudarisman. 2013. Pembelajaran Biologi Menggunakan Pendekatan CTL (Contextual Teaching And Learning) Melalui Media Flipchart Dan Video Ditinjau Dari Kemampuan Verbal Dan Gaya Belajar 1. BIOEDUKASI Volume 6, Nomor 2.

[7] Undang-undang Republik Indonesia Nomor 20 tahun 2003 tentang Sistem Pendidikan Nasional
[8] Sobana, 2020. Dampak Pandemi Covid 19 Terhadap Pendidikan Dan Pelatihan Aparatur, Jurnal Pendidikan Indonesia Vol. 1 No. 1 Oktober 2020

[9] Wasilah, U., Rohimah, S., Su'udi, M., 2019. Perkembangan Bioteknologi di Indonesia, Rekayasa. Journal of Science and Technology, 2019; 12(2): $85-90$

[10]Agustin, M., Puspita, R. D., Nurinten, D., \& Nafiqoh, H. 2020. Tipikal Kendala Guru PAUD dalam Mengajar pada Masa Pandemi Covid 19 dan Implikasinya. Jurnal Obsesi: Jurnal Pendidikan Anak Usia Dini, 5(1), 334-345.

\section{PENULIS}

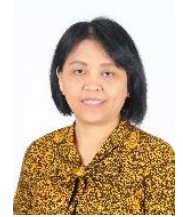

Exsyupransia Mursyanti, prodi Biologi, Fakultas Teknobiologi, Universitas Atma Jaya Yogyakarta.

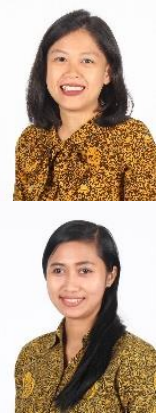

Stefani Santi Widhiastuti, prodi Biologi, Fakultas Teknobiologi, Universitas Atma Jaya Yogyakarta.

Dewi Retnaningati, prodi Biologi, Fakultas Teknobiologi, Universitas Atma Jaya Yogyakarta. 